\title{
Absenteeism and Factors Affecting Absenteeism
}

\author{
Asha TAniyan'
}

${ }^{1}$ Tutor, Rufaida College of Nursing, Jamia Hamdard.

DOI: https://doi.org/10.24321/2455.9318.201807

\begin{abstract}
Attendance is an important factor in school success among children and youth. Studies show that better attendance is related to higher academic achievement for students of all backgrounds, but particularly for children with lower socioeconomic status Beginning in kindergarten, students who attend school regularly score higher on tests than their peers who are frequently absent. Chronic truancy (frequent unexcused absence) is a strong predictor of undesirable outcomes in adolescence, including academic failure, dropping out of school, substance abuse, gang involvement, and criminal activity. Many factors can contribute to student absenteeism. Considering this ever-increasing menace of absenteeism, a descriptive study was conducted to assess the point prevalence of absenteeism and factors influencing absenteeism among student nurses in a selected college of nursing of Delhi, and to explore the factors influencing absenteeism among student nurses. The research approach adopted for the study was quantitative with descriptive research design. The tool used for data collection was a structured opinionaire and record analysis. The sample comprised of nursing students of Rufaida College of Nursing, selected by using total enumeration sampling technique. The study revealed that the majority of the student nurses (81\%) were having attendance above $75 \%$ whereas only $19 \%$ were having attendance below $75 \%$. It was found that the days following or prior to holidays or weekends saw maximum number of student absenteeism.
\end{abstract}

Keywords: Absenteeism, Point prevalence, Student nurses

\section{Introduction}

Education is not merely the delivery of knowledge, skills and information from teachers to students. Pupil is able to perceive accurately, think clearly and act effectively to achieve self-selected goals and aspirations. The study of absenteeism is very important for any college. The word absenteeism means the absence of student from class when the student is scheduled to be present at school/ college. Absenteeism of a student is defined as a period of time when teacher has no information in advance that the student will not report for class, if she has taken leave to which she is entitled, or on ground of sickness or in case of accident. Thus, absence may be authorized or unauthorized, willful or caused by circumstances beyond the teacher's control. ${ }^{1}$ Attendance is an important factor in school success among children and youth. Studies show that better attendance is related to higher academic achievement for students of all backgrounds, but particularly for children with lower socioeconomic status. Factors that contribute to absenteeism may be family health or financial concerns, poor school climate, drug and alcohol use, transportation problems, and differing community attitudes towards education. ${ }^{1,2}$

The absenteeism among university students can lead to much negative effect such as the student pointer can drop and many social problems may happen. The university also will not be able to produce quality graduates. University has its own responsibility to produce a knowledgeable, skilled and disciplined graduate student so that after graduation, the students can easily get a job and become good citizens, which can help economy of the country develop. Student absenteeism is a major concern for university education worldwide. Despite strict rules, absenteeism is an on-going problem in universities. ${ }^{3}$ Due to paucity of research in Indian setting on the factors influencing absenteeism, we chose to conduct this study.

E-mail Id: asha.aniyan86@gmail.com

Orcid Id: http://orcid.org/0000-0002-4174-1126

How to cite this article: Aniyan AT. Absenteeism and Factors Affecting Absenteeism. Int J Nurs Midwif Res 2018; 5(1): 27-31. 


\section{Materials and Methods}

The purpose of the present study was to assess the point prevalence of absenteeism among the student nurses in a selected college of nursing of Delhi and to explore the factors influencing absenteeism. A descriptive cross-sectional study was conducted during the academic year 2017-18, among students enrolled in B.Sc. (H) Nursing Program at Rufaida College of Nursing, Jamia Hamdard. The formal administrative approval was obtained from the concerned authority to conduct the study. Sampling technique used for selection of sample was total enumeration technique, and records of 211 students were analyzed for assessing the point prevalence of absenteeism. This demonstrated that 40 students were having less than $75 \%$ attendance. For assessing the factors influencing absenteeism, those (40) study subjects were used, as per the norms of the university (minimum 75\% attendance is required for attempting the examinations). Record analysis was used to assess the point prevalence and a structured opinionaire was used to assess the factors affecting absenteeism. The opinionaire consisted of two parts. Part-A consisted of 12 questions related to demographic data and Part-B consisted of an opinionaire to elicit the factors that may affect absenteeism. The data were collected and analyzed using descriptive statistics.

\section{Result}

Table 1.Attendance Record Analysis of B.Sc. (H) Nursing I, II, III and IV Year Students

\begin{tabular}{|c|c|c|c|c|c|}
\hline $\begin{array}{c}\text { Class Attendance } \\
\text { Percentage (\%) }\end{array}$ & $\begin{array}{c}\text { B.Sc. }(\mathrm{H}) \text { Nursing } \\
\text { I year }\end{array}$ & $\begin{array}{l}\text { B.Sc. (H) Nursing } \\
\text { II year }\end{array}$ & $\begin{array}{l}\text { B.Sc. }(\mathrm{H}) \text { Nursing } \\
\text { III year }\end{array}$ & $\begin{array}{l}\text { B.Sc. }(\mathrm{H}) \text { Nursing } \\
\text { IV year }\end{array}$ & $\begin{array}{r}\mathrm{N}=2 \perp \\
\text { Total Students }\end{array}$ \\
\hline$<75$ & 4 & 13 & 19 & 4 & 40 \\
\hline $75-79$ & 5 & 6 & 10 & 1 & 22 \\
\hline $80-84$ & 10 & 9 & 8 & 2 & 29 \\
\hline $85-89$ & 19 & 12 & 14 & 4 & 49 \\
\hline $90-94$ & 7 & 9 & 5 & 19 & 40 \\
\hline $95-99$ & 9 & 3 & 0 & 19 & 31 \\
\hline 100 & 0 & 0 & 0 & 0 & 0 \\
\hline Total & 54 & 52 & 56 & 49 & 211 \\
\hline
\end{tabular}

Of the total (211) students enrolled in B.Sc. (H) Nursing program in the academic year (2016-17), 40 (18.9\%) students had attendance less than $75 \%$ (minimum attendance percentage required for writing the examinations as per the university byelaws), of which 19 (47\%) numbers of students were in III year followed by 13 (33\%) in II year. Both I and IV year students had recorded least number of student absenteeism, i.e., 4 (10\%).

Further, these 40 students (with attendance less than 75\%) were included to assess the factors influencing absenteeism.

Table 2.Frequency and Percentage Distribution of Subjects in Terms of Their Sociodemographic Profile

\begin{tabular}{|c|c|c|c|}
\hline S. No. & Variables & Frequency & Percentage \\
\hline 1 & Age & & 32.5 \\
\hline & $18-19$ & 20 & 50 \\
\hline & $20-21$ & 7 & 17.5 \\
\hline 2 & $22-23$ & & 5 \\
\hline & Gender & 2 & 95 \\
\hline 3 & Male & 38 & 37.5 \\
\hline & Female & 15 & 35 \\
\hline & Religion & 14 & 20 \\
\hline & Hindu & 8 & 7.5 \\
\hline
\end{tabular}




\begin{tabular}{|c|c|c|c|}
\hline & Urban & 37 & 92.5 \\
\hline & Rural & 3 & 7.5 \\
\hline \multirow[t]{4}{*}{5} & Schooling & & \\
\hline & Private school & 28 & 70 \\
\hline & Government school & 9 & 22.5 \\
\hline & Missionary School & 3 & 7.5 \\
\hline \multirow[t]{5}{*}{6} & Class XII percentage & & \\
\hline & Below 60 & 1 & 2.5 \\
\hline & $61-75$ & 20 & 50 \\
\hline & 76-85 & 14 & 35 \\
\hline & $86-100$ & 5 & 12.5 \\
\hline \multirow[t]{7}{*}{7} & Mother's education & & \\
\hline & Illiterate & 2 & 5 \\
\hline & Primary & 4 & 10 \\
\hline & Secondary & 6 & 15 \\
\hline & Higher secondary & 6 & 15 \\
\hline & Diploma & 6 & 15 \\
\hline & Degree and above & 16 & 40 \\
\hline \multirow[t]{7}{*}{8} & Father's education & & \\
\hline & Illiterate & 2 & 5 \\
\hline & Primary & 2 & 5 \\
\hline & Secondary & 3 & 7.5 \\
\hline & Higher secondary & 4 & 10 \\
\hline & Diploma & 6 & 15 \\
\hline & Degree and above & 23 & 57.5 \\
\hline \multirow[t]{6}{*}{9} & Current residence & & \\
\hline & In university hostel & 23 & 57.5 \\
\hline & Outside university hostel with family & 11 & 27.5 \\
\hline & Outside university with relatives & 2 & 5 \\
\hline & Outside university with friends & 0 & 0 \\
\hline & Paying guesthouse & 3 & 7.5 \\
\hline \multirow[t]{5}{*}{10} & Meals & & \\
\hline & University cafeteria & 2 & 5 \\
\hline & Outside the university & 4 & 10 \\
\hline & At hostel & 22 & 55 \\
\hline & At home & 12 & 30 \\
\hline \multirow[t]{3}{*}{11} & Use of psychoactive drugs & & \\
\hline & Yes & 0 & 0 \\
\hline & No & 40 & 100 \\
\hline \multirow[t]{3}{*}{12} & Siblings in the university & & \\
\hline & Yes & 9 & 22.5 \\
\hline & No & 31 & 77.5 \\
\hline
\end{tabular}

Table 2 describes demographic data on age, gender, religion, social background, schooling, percentage secured in class XII, mother's and father's education level, current residence, venue for meal, use of psychoactive substances and siblings studying in the same university. Half of the subjects $50 \%$ (20) were in age group 20-21years, $32.5 \%$ (13) of subjects were in age group $18-19$ and $17.5 \%$ (7) subjects were in age group $22-23$ years. Most of the subjects $95 \%$ (38) were female and $5 \%$ (2) were male. $37.5 \%$ (15) followed Hinduism, 35\% (14) practiced Islam, $20 \%$ (8) subjects followed Christianity and 
rest $7.5 \%$ (3) followed other religions. 92.5\% (37) subjects belonged to urban background and only $7.5 \%$ (3) subjects were from rural background.

$70 \%$ (28) subjects had done their schooling at private schools and approximately one third $22.5 \%$ (9) subjects at government schools and only $7 \%$ (3) had done their schooling at missionary schools. Half of the subjects $50 \%$ (20) had scored $61-75 \%$ in class XII, 35\% (14) subjects $76-85 \%, 13 \%$ (5) subjects $86-100 \%$ and only $2.5 \%$ (1) had scored below $60 \%$ in class XII. Data for education level revealed $40 \%$ (16) mothers were postgraduates as compared to their male counterparts $57.5 \%$ (23).

More than half $57.5 \%$ (23) subjects were staying in university's hostel, approximately one fourth $27.5 \%$ (11) outside the university with family, 5\% (2) outside the university with relatives, $2.5 \%$ (1) in paying guesthouses and $7.5 \%$ (3) were staying in rented rooms with friends. $55 \%(22)$ subjects were having meals at the hostel, $30 \%(12)$ at home, $10 \%$ (4) outside the university and only 5\% (2) at university's cafeteria. None of the subjects were consuming psychoactive substances. Only $22.5 \%$ (9) subjects were having their siblings studying in this same university. unfavorable responses and $27 \%$ (54) were favorable responses. Infrastructure-centered factors got the highest favorable response $47 \%$ (113) among all the factors and $52 \%(127)$ were unfavorable responses whereas in socialcentered, only $21 \%$ (43) were favorable responses and $65 \%$ (77) subjects had shown unfavorable responses. In consequences-centered, 33.3\% (40) were favorable responses and $66.6 \%$ (80) were unfavorable responses.

It was observed that students were not satisfied with the infrastructure including the classrooms and the routine of clinical duties was also found to be a contributing cause of increasing absenteeism. It was also found that the days following holidays or weekends saw maximum number of student absenteeism.

\section{Discussion of Findings}

Absenteeism refers to a situation where a student does not attend lectures, practice or any education activities. In a study conducted by Faiza, it was found that the prevalence of absenteeism among nursing students was $29.4 \%$. Absenteeism was more prevalent in males than females which was $41.1 \%$ and $26.5 \%$ respectively. ${ }^{4}$ the results of

Table 3.Percentage Distribution of Responses of Student Nurses on Factors Influencing Absenteeism

\begin{tabular}{|c|c|c|c|c|}
\hline S. No. & Factors & Response & Total & Percentage \% \\
\hline \multirow[t]{3}{*}{1} & \multirow[t]{3}{*}{ Teacher centered } & Favorable & 73 & 30.41 \\
\hline & & Unfavorable & 167 & 69.58 \\
\hline & & Total & 240 & 100 \\
\hline \multirow[t]{3}{*}{2} & \multirow[t]{3}{*}{ Pupil centered } & Favorable & 257 & 33.81 \\
\hline & & Unfavorable & 503 & 66.18 \\
\hline & & Total & 760 & 100 \\
\hline \multirow[t]{3}{*}{3} & \multirow{3}{*}{ Personal centered } & Favorable & 54 & 27 \\
\hline & & Unfavorable & 146 & 73 \\
\hline & & Total & 200 & 100 \\
\hline \multirow[t]{3}{*}{4} & \multirow[t]{3}{*}{ Infrastructure centered } & Favorable & 113 & 47.08 \\
\hline & & Unfavorable & 127 & 52.91 \\
\hline & & Total & 240 & 100 \\
\hline \multirow[t]{3}{*}{5} & \multirow[t]{3}{*}{ Social centered } & Favorable & 43 & 21.5 \\
\hline & & Unfavorable & 77 & 64.5 \\
\hline & & Total & 120 & 100 \\
\hline \multirow[t]{3}{*}{6} & \multirow[t]{3}{*}{ Consequences centered } & Favorable & 40 & 33.33 \\
\hline & & Unfavorable & 80 & 66.66 \\
\hline & & Total & 120 & 100 \\
\hline
\end{tabular}

Table 3 illustrates the responses given by the study subjects regarding the factors influencing absenteeism. In teacher-centered factors, nearly $70 \%$ (167) were unfavorable responses whereas $30 \%$ (73) were favorable responses. In pupil-centered factors, 66\% (503) were unfavorable responses and 34\% (257) were favorable responses. In personal-centered factors, 73\% (146) were the present study were similar to this study, which also found out that there were about $18.9 \%$ students having attendance less than the minimum requirement as directed by the university.

A similar study was conducted by Wadesango and Machingambi with the aim to investigate the extent of 
student absenteeism in selected universities in South Africa, and to explore why students absent themselves from classes and examine the implications of student absenteeism. The study revealed that student absenteeism was rampant in the universities under study due to reasons such as lack of subject interest, poor teaching strategies by lecturers, unfavorable learning environment, too much of socialization, part-time jobs to augment meager bursaries granted by various sponsors and poor relations with the lecturers. The study also found an inverse relationship between student absenteeism and course performance. ${ }^{5}$ These findings were comparable to the present study, which also observed poor infrastructure to be a contributing factor along with practical session.

A study conducted by Timmins and Kalliszer explores absenteeism patterns and trends among a group of third-year student nurses. It was found that absenteeism commencing on either Mondays or Fridays accounted for more than half of the absenteeism episodes in the group. Voluntary absence was reported to be a feature of this group, which occurred more frequently from lectures than ward duties; the main reasons cited for absence from both lectures and ward duties were personal and social commitments and stress. ${ }^{6}$ Findings of the present study also suggested that absence had a pattern of predictability with the holidays or weekends.

\section{Acknowledgments}

The authors take this opportunity to express their sincere thanks to all class teachers of B.Sc. $(\mathrm{H})$ Nursing program at Rufaida College of Nursing, Jamia Hamdard, for providing them with the logistic support and allowing them to fetch data from their records. The authors would also like to acknowledge and thank students of B.Sc. $(\mathrm{H})$ Nursing $4^{\text {th }}$ year - Ms. Pema Bhuti, Ms. Kalsang Choedon, Ms. Saumya Viju, Ms. Akansha, Ms. Deeksha, Ms. Zainab, and Ms. Nabila for their tireless effort in data collection and compilation of the research work.

\section{Conflict of Interest: None}

\section{References}

1. Ready DD. Socioeconomic disadvantage, school attendance and early cognitive development: The differential effects of school exposure. Sociology of Education 2010; 83(4): 271-86.

2. Epstein JL, Sheldon SB. Present and accounted for: improving student attendance through family and community involvement. Journal of Educational Research 2002; 95(5): 308-18.

3. Syarifah ST. Factors influencing student's absenteeism in university level. Faculty of Cognitive Sciences and Human Development, University Malaysia Sarawak, https:// ir.unimas.my/3448/1/Factors\%20influencing\%20 student\%27s\%20absenteeism\%20in\%20university\%20 level\%20(Universiti\%20Malaysia\%20Sarawak).pdf.

4. Faiza S, RNI AN. Prevalence of absenteeism among nursing students. International Journal of Medical and Health Sciences 2015: 1-10.

5. Wadesango N, Machingambi S. To study the reasons of absenteeism and find out remedies. Journal Social Science 2011; 26(2): 89-97.

6. Timmins F, Kalliszer M. Absenteeism among nursing students - Fact or fiction? Journal of Nursing Management 2002; 10(5): 251-64.

Date of Submission: 2018-03-27 Date of Acceptance: 2018-04-27 